\title{
Erratum to: Genome-wide exploration of silicon (Si) transporter genes, $L s i 1$ and $L s i 2$ in plants; insights into Si-accumulation status/capacity of plants
}

\author{
Recep Vatansever • Ibrahim Ilker Ozyigit • Ertugrul Filiz • Nermin Gozukirmizi
}

Published online: 31 January 2017

(C) Springer Science+Business Media New York 2017

\section{Erratum to: Biometals}

DOI 10.1007/s10534-017-9992-2

Due to an unfortunate turn of events, the surname of the last author appeared incorrectly in the original publication and should have read Gozukirmizi.
The correct representation of the authors' names is listed here and should be treated as definitive.

The online version of the original article can be found under doi:10.1007/s10534-017-9992-2.

R. Vatansever · I. I. Ozyigit

Department of Biology, Faculty of Science and Arts,

Marmara University, Istanbul, Turkey

E. Filiz ( $₫)$

Department of Crop and Animal Production, Cilimli

Vocational School, Duzce University, Duzce, Turkey

e-mail: ertugrulfiliz@gmail.com

N. Gozukirmizi

Department of Molecular Biology and Genetics, Faculty

of Science, Istanbul University, Istanbul, Turkey 